\title{
Globalizations
}

\section{Making or unmaking a movement? Challenges for civic activism in the global governance of migration}

\section{Aleksandra Ålund \& Carl-Ulrik Schierup}

To cite this article: Aleksandra Ålund \& Carl-Ulrik Schierup (2018): Making or unmaking a movement? Challenges for civic activism in the global governance of migration, Globalizations, DOI: $10.1080 / 14747731.2018 .1446599$

To link to this article: https://doi.org/10.1080/14747731.2018.1446599

ఠ

(C) 2018 The Author(s). Published by Informa

UK Limited, trading as Taylor \& Francis Group

曲 Published online: 13 Mar 2018.

Submit your article to this journal 준

Q View related articles ¿

View Crossmark data \lceil 


\title{
Making or unmaking a movement? Challenges for civic activism in the global governance of migration
}

\author{
Aleksandra Ålund and Carl-Ulrik Schierup
}

Linköping University, Linkoping, Sweden

\begin{abstract}
This article discusses dilemmas of global civic activism from a neo-Gramscian perspective as both subordinated and a potential challenge to hegemonic neoliberal order. With the investigational focus on the People's Global Action on Migration, Development and Human Rights (PGA) event, the space for civic activism relating to the intergovernmental Global Forum on Migration and Development (GFMD) and its associated Civil Society Days and Common Space is analysed. The article asks how the future of PGA activism may be influenced by its formalized representation within the GFMD. It posits that the PGA has landed at a crossroad between becoming a global activist counterhegemonic movement to a dominant neoliberal migration policy and being captured in a tokenist subordinated inclusion within a truncated 'invited space' for interchange. This ambiguous position jeopardizes its impact on global migration governance, discussed with reference to theories of transversal politics and issues of counterhegemonic alliance-building.
\end{abstract}

\section{KEYWORDS}

Civic activism; global governance; international migration; neoliberalism; social movements

\section{Introduction}

At the centre of this paper are emergent civil society movements concerned with migrant's rights, and the political economy of neoliberal globalization. They question the precarisation of work and citizenship as well as dominant refugee and asylum politics. Such issues have since long been the object of critical research on civic activism and social movements.

Towards the end of the 1980s, Hall (1987) initiated a discussion of the relevance of Gramscian thought for understanding and acting politically in a profoundly transformed present. We live today, he observed, 'in an era when the old political identities are collapsing', raising questions on new political forms and a new cultural order. A new order emerges with a 'multiplicity of dispersed wills', 'heterogeneous aims', a 'pluralisation of modern cultural identities', and multiple centres of power (Hall, 1987, p. 20). The problem faced, Hall argued, is related to the capability of addressing this diversity of identities and social forces, unifying them within a common project across their differences. That means understanding - from an overall Gramscian perspective - civil society as an arena for mobilization, with contemporary social movements as a new political subject, subordinated to while also challenging neoliberal hegemony making.

Contemporary civil society organizations (CSOs) and movements demonstrate new forms of political participation, putting into question the growing democratic deficit of formal politics as well as 
'partnerships' between state, market, and civil society (Ålund, Schierup, \& Neergaard, 2017). Inclusion through 'integrative' co-optation may mediate change but may, at the same time, defuse counterhegemonic discourses and activism of contending movements through appropriative consensus-making (Coy \& Hedeen, 2007 [2005]), carrying 'uncertain futures for democratic possibilities' (Walton \& Udayagiri, 2003, p. 309). From this vantage point, this paper aims to contribute to the critical theoretical discussion of what we, with Purcell (2009a, p. 291), call counterhegemonic movements - that is, 'movements that can both undermine the dominance of neoliberalism and construct concrete alternatives to it' (Walton \& Udayagiri, 2003).

Grounded in a neo-Gramscian approach (Gill, 2003), we see our present historical moment as tendentially 'non-hegemonic' (Cox, 1983; Deak, 2005). This signifies more specifically an ostensibly hegemonic neoliberal 'end of history' in crisis challenged by cycles of contending movements (Funke, 2014). Yet, a morbid 'arrest of time' (Brown, 2005, p. 7) in the hiatus of which the new to be born can only be glimpsed through a looking glass darkly. Following Purcell (2009b, pp. 143-144), we discuss how unstable articulations of neoliberal hegemony mired in contradictions and legitimacy problems are challenged by counterhegemonic projects carried forth by movements of civil society; '[c]ounter-projects' that are not only 'possible', but indeed 'inevitable'. This posits social movement issues and prospects, Purcell (2009a, pp. 295-296) contends, in the orbit of the original Gramscian argument on hegemony by stating that 'the social field is too fragmented for one class (or, more generally, one group) to rule on its own'. It must 'widen itself ... propagating itself throughout society ... broadening its political identity' to incorporate, appropriate and subordinate a wider array of ideopolitical perspectives and interests (Purcell, 2009a). From this overall position, we interrogate which challenges, in terms of identity, direction, and position, are faced by global, network-based movements from two analytical perspectives; the internal dynamics in the formation and articulation of movements, and challenges faced by movements connected with a subordinated position within formalized spaces of governance. The first perspective is concerned with the constitution of networks of equivalence as developed by Purcell (2009a, p. 291) as an 'articulation of differentiated but equivalent popular struggles'. That is, broad coalitions of movements and groups that expose the political field as 'irreducibly plural', merging sameness and difference in terms of identity and agenda. The other main perspective concerns the limits of what has been theorized in terms of invited spaces (Gaventa, 2006) for civil society participation within intergovernmental fora.

We illustrate cardinal points through empirical reference to the case of the global network designated the People's Global Action on Migration, Development and Human Rights (here forth the $P G A) .{ }^{1}$ The PGA is a forum for a multitude of civil society activists; organizations, networks, and movements, including migrant and migrant advocacy organizations and individuals, researchers, trade unions, and faith organizations. It is mobilized as a campaign event during world governmental summits within the Global Forum on Migration and Development (GFMD), as well as periodically occurring UN summits concerned with migration and development. The PGA has sought to introduce an agenda onto the GFMD that represents the concerns of migrants, and to raise critical perspectives on human rights, labour rights, sustainable development, and the need to contest precarious livelihoods and the excessive exploitation of millions of the world's migrants.

The GFMD was initiated following the UN High Level Dialogue (UNHLD) on Migration and Development in 2006. It is the most inclusive state-led forum between governments, concerned with developing common policies for international migration. Although non-binding, and situated outside the UN system, it presents the most ambitious intergovernmental deliberations on a global governance framework on migration. Since 2007, the GFMD has figured as an arena for dialogue 
between sending, receiving, and transiting states on standards for global migration governance. Yet, the GFMD process has remained embedded in the UN framework, homecoming to regularly occurring UNHLD follow-ups, the latest of which took place in New York in 2013.

The forum is meant to be informed by the exchange of ideas with international organizations, civil society, and business. Since its inception, the so-called Civil Society Days (CSD) have been organized as a side event to the GFMD meetings. Further, since the emergence of PGA (in 2006), as a collaborative network of CSOs on the issues of migration and development, the quest for human/labour rights has become a central demand to voice within the formalized fora of the GFMD/UNHLD process. However, the PGA has come to face problems concerning deliberations within fora for global governance of migration. While the PGA has created a space for repeated appearances preceding and subsequently represented within GFMD/CSD, the movement has landed at a crossroad between representing an activist counterhegemonic movement and a position marked by a subordinated inclusion within the GFMD/UNHLD process. On this background, we reflect upon the trajectories of contestative movement activism in relation to contemporary governance.

While others have ventured in some detail into the constitution of a contestative global civil society movement for migrant rights (Piper, 2015; Rother, 2009), our purpose is to illustrate points in our theoretical discourse through commenting on impasses encountered by the PGA at crucial crossroads in the later part of its trajectory. The question we posit is whether the 'PGA' has become the insignia of a social movement in unmaking rather than in the making?

\section{Progress and prospects for the making of a "new' global movement}

A growing body of research has called attention to the issue of the 'new' in contemporary social movements, depicting differences between what is perceived as 'old', 'new', and 'new-new' social movements. New social movement theorists (Melucci, 1989; Offe, 1985; Touraine, 1987) claim these movements differ from the 'old' - in particular from the labour movement - mainly in terms of more composite social bases (mixed) and forms of organization (localized, informal, and temporal). Feixa, Pereira, and Juris (2009) argue that globalization has resulted in 'new-new' globalized social movements (NNSM). While organized around informal networks, NNSM link locally rooted struggles to national and global events. Thus, they are 'like the neoliberal system these movements oppose', situated in a globally networked space (Feixa, Pereira, \& Juris, 2009, pp. 421-422). NNMS, they continue, 'highlight the transformations and social conflicts associated with the consolidation of informational capitalism', merging generations, genders, ethnicities, and territories, within unstable networks.

As originally imagined and devised, the highly composite global network and yearly event, the PGA, demonstrate the importance and veracity of critical interventions on issues connected with the emergence of a neoliberal migration policy regime (Schierup, Ålund, \& Likić-Brborić, 2015). The PGA was first constituted as a global civil society network event which was critically counterpoised to the UNHLD on International Migration and Development in 2006. As noted above, the UNHLD resulted in the institutionalization of the intergovernmental forum, the GFMD, as a yearly event. Since then, the PGA has recurrently taken place, parallel to, and critically counterpoising, yearly GFMD intergovernmental meetings. This began in Brussels 2007, and was followed by Manila 2008, Athens 2009, Mexico City 2010, Geneva 2011, Port Louis 2012, New York City 2013 (in conjunction with a second UNHLD), Stockholm 2014, Istanbul 2015, Dhaka 2016, and Berlin 2017. In its original form, the PGA brought together a multitude of critical networks, organizations, and movements from across six continents, while tilting towards a marked 'southern' political and 
organizational perspective. It amalgamated perspectives of 'new' diaspora movements and migrant advocacy organizations with those of a multiplicity of organizations of labour, representing 'old' as well as 'new' moral-political and organizational union orientations. The PGA as a whole appeared indeed in the stature of a 'new-new' type of global network and event. Concerning an original counterhegemonic orientation, this invites comparison with the World Social Forum on Migrations (WSFM) - founded in São Paulo as a key feature of the World Social Forum (WSF) - indicating that 'another world is possible'.

The contestative character of the PGA, as an event born out of the alter-globalization movement, was clearly expressed in its first world summits, organized as counterpoints to GFMD intergovernmental meetings, including the PGA in Mexico City, 2010. 'We are human beings with rights to mobility, freedom of speech, decent work and social protection - not a commodity', is a pledge cited from the PGA's statement targeted at the Mexican GFMD governmental forum. It echoes Polanyi's (2001 [1944]) radical critique in the Great Transformation, denouncing the unchecked commodification of labour, embodied in the migration of precarious workers from the south.

The 'International Working Group' (IWG), responsible for organizing the 2010 PGA in Mexico City, had ambitious goals in terms of building a movement that would shape a continuous policy deliberation in favour of labour, social, civic, and human rights for migrants and rebalance asymmetric power relations in the governance of migration and development in favour of 'southern' interests. The IWG included migrant umbrella federations, organizations, and networks situated in Asia, the Americas, Africa, and Europe (representing numerous community-based migrant organizations and migrant advocacy groups), as well as the Global Unions Federation (representing affiliated unions distributed over a wide array of trades) and a Mexican-based critical think tank (PGA, 2010). The Mexican PGA venue gathered more than 800 delegates from across the 6 continents, representing migrant/diaspora organizations, migrant advocacy organizations, faith-based solidarity organizations, trade unions, and academics. The venue gave witness to what Motta (2011, p. 179), in her discussion of academic versus social movement epistemology, described as 'developing utopias as part of the process of creating alternative logics of being and doing' trusting that 'movements ... can develop theoretical knowledge via a systematisation based on their political experiences'.

Regarding the importance of Mexico 2010, it should be added that the PGA obtained for the first time the opportunity to delegate representatives to CSD and a newly instituted 'Common Space' (CS) for governmental/civil society interchange, thereby acquiring a formally acknowledged place relating to the GFMD. Yet, from our participation in a range of plenums and workshops, we could also observe a range of actual or potential rifts between the motley collection of widely different networks and organizations, represented in or relating to the PGA/CSD/CS. They counted potential dissentions between labour unions and other CSOs, between different regionally situated organizations and networks, and organizations with differential positionality relating to regional, national, or local governance frameworks. This calls for an analysis of the potential challenges and pitfalls contingent on the contemporary plurality and fragmented character of social movements, and of perspectives for their formation as political subjects.

It is problematic that, as discussed by Rother (2013), there is an innate controversy between civil society actors that rely on 'outside-inside' as opposed to 'outside' strategies and tactics in relation to hegemonic discourses and institutions of governance in promoting their aims. Nevertheless, an 'outside-inside' strategy dominates the direction of the PGA. Endeavouring to promote a rights-based migration regime, it has built on global grassroots mobilization, but with the rationale of instituting a civil society agenda within major intergovernmental fora; a war of position for neoliberal times (Gramsci, 1971). A rival civil society tactic, reminiscent of a contemporary war 
of movement, has aimed to criticize and counter this dominant strategy. It puts its stakes on global alliance-making from the bottom-up, with insistent claims from the 'outside' matched by a distanced scepticism rejecting a disciplining of civil society within intergovernmental fora. ${ }^{2}$ This unsettled enigma has followed the global movement for migrant rights from its beginnings until today.

\section{Networks of equivalence - social movement as a political subject}

Departing from a Gramscian understanding of CSO and its relation to policy, Purcell (2009a) discusses the ways that fragmented struggles within global movements of the present can be brought together without ending in a uniform whole or becoming subordinated to other struggles. Like Hall (1987), he sees the work of Gramsci as the starting point to reach beyond a reductionist approach to political movements and, at the same time, still develop a collective and coordinated struggle with the potential to transform existing power relations.

With this in mind, Purcell develops the notion of 'networks of equivalence', perceived as broad coalitions that bring 'together many different struggles, movements and groups' (2009a, p. 279). In this process of coming together, there is a complex relation between sameness and difference (Purcell, 2009a, p. 279). With reference to Gramsci (1971) and Laclau and Mouffe (1985), Purcell elaborates on the notions of articulation and equivalence. This is devised to 'capture how groups join together into a counterhegemonic formation', constructing a shared common sense and a collective articulation of a new political will 'without dissolving differences into a homogenous unity' (Purcell, 2009a, p. 303), a coalitional movement amalgamating multiple subject positions.

\section{Transversal dialogues?}

This issue of a movement becoming a political subject in its own right begs for widening the space for different voices to be heard. It invites, in effect, a recapturing of a rich legacy in feminist debates.

Criticism of ethnocentricity in the mainstream feminist discourse was initiated by black feminists in the United States and Britain in the early 1980s. The essential aspects of this critique concerned the problems of either the 'invisibility' of black and ethnic women in the writings of white feminists, or their 'visibility' as victims. But, it was particularly the critique of the 'victim' perspective that opened up for new understandings of the relationship between colonial and post-colonial imaginaries, images and the struggles for the Self among oppressed peoples.

The recognition of black, ethnic, and migrant women in the texts and politics of mainstream feminism has since the 1990s been a prominent theme within international feminist studies. The perception of diversity as a threat has gradually been replaced by claims for the development of a politics of recognition for different voices in joint 'transversal' dialogues (Yuval-Davis, 1999). In order to find new modes of articulation between the universal and particular concepts such as 'differentiated universalism' (Lister, 1996) and 'transversal dialogue' (Yuval-Davis, 1999), express the need to bring forth the recognition of socio-cultural particularity into universalism, without overshadowing socially constructed inequalities appearing as divergences (Lister, 1996).

Particularly, Yuval-Davis (1999) discusses the notion of transversal dialogue within the context of 'transversal politics', aiming to bridge diversity across, for example, ethnic and political boundaries. She criticizes what she sees as an overstated confidence in universalism in discourses of feminist sisterhood, but also a limitless relativism of 'difference' caring with it cleavages and fragmentation. Yuval-Davis argues that differences, related to social, economic, and political power, should be acknowledged without replacing the notion of equality. Relating to the epistemology of stand 
point feminism, she explains the need to recognize that just one position (gender for example) is 'unfinished'. She sees, at the same time, the need for the recognition of an interconnection of other positions in terms of social, economic, political, or cultural inequality. To this end, the notion of transversal dialogue, Yuval-Davis alleges, could be important in advancing democratic deficits within contemporary social movements in order to avoid either 'over universalism' or 'over relativism'. Thus conceived, 'transversal politics' stands out as an alternative to an assimilationist, ostensibly 'universalistic' politics on the traditional left, but at the same time also to a fragmenting identity politics obsessed with 'difference'.

Let us now relate transversal dialogues to the issue of the global movement for migrant rights. In this connection, there is a diacritical watershed between labour unions, on the one side, and other organizations and movements of civil society such as migrant organizations and an array of NGOs, on the other. They have different management styles and approaches to tackling inequality. While the latter tend to congregate around demands propagating 'human rights', often packed in a moralistic discourse, the legitimacy and mandate of the former do not depend on a human rights discourse. Rather, trade unions obtain their organizing mandate from workers who need collective representation to face employers and the state (Schierup, Munck, Likic-Brboric, \& Neergaard, 2015, p. 12). They are often very formal organizations, which tend not to engage with the informal economy or people whose livelihoods are most precarious. NGO programmes, on their part, are often 'concerned with manifestations of extreme poverty and are accustomed to working in the informal sector but they have little sense of the significance of labour rights as such' (Piper \& Grugel, 2015). While trade unions may be slow to act, although have long term and overtly political horizons, NGOs are often project-based, dependent on a constant struggle for government or corporate funding, and tend towards settling with a 'watchdog role'.

On this background, a dialogue traversing differences and potential controversies is necessary (Piper \& Grugel, 2015) in order to accomplish a counterhegemonic formation capable of sustaining demands for a restructured global governance of migration. Such a dialogue indeed was vivid on the occasion of the 2010 PGA and that year's CS days in the GFMD. But, later events would demonstrate that a window of opportunity limited to vague promises of 'respect for human rights' does not provide an adequate discursive and institutional space for productive transversal dialogue and powerful and sustainable alliances traversing these divides within a wider civil society.

\section{The limits of invited spaces}

Any movement of civil society, operating within the framework of dominant institutions - be they local, national, or transnational - face risks connected with co-optation. It has indeed been inferred that the current public attention paid to civil society and new social movements are related to the preceding decades' neoliberal reorientation - a process in which CSOs have become key players involved with the expansion of market principles. Kaldor (2003), for one, discussing the dilemmas of global civil society in the context of wars and complex emergencies, links imaginaries and agency of contemporary social movements to the transformation of civil society from an 'activist' into a neoliberal model. Here, civil society functions as a substitute for the state, which has pulled back from public service delivery, with the consequence of social movements turning into a market of NGOs/ INGOs. Becoming institutionalized, they service functions of a retiring state, including human rights consultation, combating poverty, conflict resolution, education, and training in democracy and citizenship. In contemporary development studies, CSO/ICSOs have increasingly been seen and engaged as central agents for the promotion of democracy in the governance of developmental 
processes. But, as contended by Veltmeyer (2009, p. 90), in the course of their engagement in 'participatory development', they have been induced to adopt tactics of subtle deliberation rather than 'confrontationalist politics of direct action'. In this process, they have often become transformed from contentious movements into institutionalized and pragmatically orientated NGOs. It is a development which is inherently connected with the dynamics and limitations of invited spaces for civil society participation in contemporary forms of governance.

The concept of 'invited spaces' originates from the work of Brock, Gaventa, and Cornwall (2001). It was further developed in different contexts by, for example, Cornwall (2002), Gaventa (2006), and Miraftab (2004, 2009). Invited spaces are, as argued by Gaventa (2006, pp. 26-27), related to participatory governance, formalized at different levels from local government, to national policy and even in global policy forums. Aiming at the creation of more open arenas for citizen participation, citizens 'are invited to participate by various kinds of authorities and organisations, be they government, supranational agencies or non-governmental organisations'. These spaces are 'either institutionalised ongoing, or more transient, through one-off forms of consultation' (Gaventa, 2006, pp. 26-27).

Referring to Cornwall (2002), Miraftab (2004) applies the notion of invited spaces in her analyses of local governance in Cape Town, South Africa. She defines invited spaces 'as the ones occupied by those grassroots and their allied non-governmental organizations that are legitimized by donors and government interventions' (Miraftab, 2004, p. 1). She furthers that 'invented' spaces are in contrast those also occupied by the grassroots and claimed by their collective action, but directly confronting the authorities and the status quo. Either through inventing new spaces, re-appropriating old ones or by moving between these spaces, grassroots movements employ counterhegemonic practices in order to 'expose and upset the normalized relations of dominance' (Miraftab, 2004). Or spoken through a Gramscian terminology, they launch a war of position (Miraftab, 2009, p. 34).

Counterhegemonic movements can be strengthened in the processes of state decentralization and the related emergence of new forms of local governance. This global trend, on one side, can provide openings for grassroots movements and other forms of social justice struggles to be recognized through local formal channels for citizen participation and claims within formalized spaces of invited dialogues. Thus, Miraftab (2009, p. 34) maintains that ' $[\mathrm{t}$ ]hrough persistent counter-hegemonic practices, these movements expose and upset the normalized relations of dominance'. But, a hegemonic move from above that institutionalizes participatory development and supports partnerships between states and NGOs can also result in the institutionalization and de-politization of grassroots movements.

\section{Pacification through appropriation?}

Pacification through appropriation appears indeed to be relevant for the development of the PGA. It resounds in comments from William Gois - the leader of Migrant Forum in Asia and an important organizer of PGA events during years - related to the PGA's position and impact, expressing worries relating to an eventual appropriation of PGA language officially for governments and multilateral organizations. Might it mean recognition or pacification, he pondered in his concluding statement at the seventh global summit of the PGA, organised in New York, October 2013, as a parallel civil society event to the UNHLD on Migration and Development, realized through commitment by local CSOs.

The New York HLD (NY HLD) had been preceded by the formation of the Global Coalition of Migration $(\mathrm{GCM})^{3}$ as a standing representative body of regional and international networks of 
migrant associations, migrant rights organizations and advocates, trade unions, faith groups and academia, covering most major regions of the globe. It was constituted on the basis of the mobilization that had taken place since 2006 within fora such as the WSFM and the PGA. It had coordinated one year's scrupulous work laid down in elaborating a five-year action plan to be presented to the governments and international organizations on the occasion of the HLD. Yet, the actual results of the HLD were less than pleasing for many.

While Gois' statement at the New York PGA reflected ambiguity, an open letter to the UN Secretary, Ban Kimoon, by the powerful Global Unions (member of the GCM) expressed, in a highly critical idiom, a frustration with the GFMD process in general, and the HLD in particular. Here, the governments and the UN's 'invited space' for deliberations with civil society stands out as at best symbolic, but in reality is monitored and disciplined by a screening process through which:

[a]t every juncture in the process, civil society members have faced significant roadblocks. For over a year, hundreds of representatives from national, regional and international organisations met in over 20 preparatory events around the world and in a UN civil society hearing to develop our inputs to the HLD. Despite this great effort to achieve shared analyses, it appears those views will be ignored. (Global Unions, 2013)

The 2013 HLD expressed a modus operandi of hegemonic governance. The letter brings this out further, through which the organizations that represent workers were effectively excluded from having any voice in the scant civil society hearings that actually took place. 'A major labour recruiter granted an award by the World Economic Forum for operating an "ethical labour supply company" was given an opportunity to address member states, as was a for-profit development firm', argues Flecker (2014) in a similar critique of the 2013 HLD, 'but not the civil society rapporteur who had been pre-selected earlier in the year, nor representatives from any organizations that represent workers'.

It was conceivably, by inference, a way of marginalizing the labour unions in their capacity of the most critical, politicized, and potentially powerful partner in the global movement for migrant rights, which had for years been developing within fora like the WSFM and the PGA, while, at the same time extending the space for more complacent and readily co-opted actors. The consequences have been dismal in sapping the engagement of international unions in the GFMD process, as well as in amputating a necessary and productive transversal dialogue between organized labour and other civil society solidarity organizations. It appeared to harbinger the beginning of the end of the PGA as a viable 'invented space' running in tandem with its co-optation and neutralization as a dynamic politicized forum.

In particular, the GFMD and UN's systems increased gravitation towards the propagation of policies mainstreaming temporary and circular migration as universal win-win-win formula (for emigration countries, receiving countries, and migrants themselves) ${ }^{4}$ has become a stumbling block for trade union engagement. In conjunction with an apparent incapability of an organized civil society to place radical alternatives onto the agenda, this has continued to estrange a variety of trade union activists, envisaging damaging effects of temporary schemes for labour and to social cohesion. Former PGA activist, Flecker (2011, p. 53), for one, concludes the following in an analysis (on behalf of the Canadian Labour congress) of Canada's temporary worker schemes, commonly held out in intergovernmental meetings as an ideal model to follow by others:

Canada's Temporary Foreign Worker Program is far from being a model initiative. Given the experiences of the Canadian labour movement, it is abundantly clear that the program's design permits the 
exploitation of migrant workers. It operates to serve employers' interests with little meaningful regard for compliance, monitoring, or enforcement of national or subnational labour standards.

\section{Screening, embedding and NGOizing civil society}

While Mexico 2010 could be seen as a high-point concerning the potentiality of the PGA as an outside-inside civil society player related to the global governance of migration, the occasion of the UNHLD can be seen as a critical marker of its decline. This concerns both its potential as a node for transversal dialogue within a variegated civil society, and its impact within the 'invited space' of the GFMD.

After the NY HLD, a further confirmation of an uncritical win-win-win formula of temporary migration as the standard baseline for deliberation, could be observed in subsequent GFMDs in Stockholm 2014 and Istanbul 2015, with Sweden and Turkey as respective host countries. It stood forth as a settled preference, which did not help to further promote the engagement of trade unions in a transversal dialogue within civil society, nor, through inference, to strengthen the clout of the PGA's 'outside-inside' strategy vis-à-vis the GFMD. The marginalization of trade union perspectives in the forum was, at the same time, exacerbated through a changing balance of power and influence between the International Labour Organization (ILO) and the International Organization for Migration in favour of the latter. It has implied a predilection towards a neoliberal perspective on the management of migration in general (Flecker, 2014; Likic-Brboric \& Schierup, 2015).

In tandem with the increasing fading out of the PGA's outside-inside strategy, post-NY HLD, the International Catholic Migration Commission (ICMC) - a since long established humanitarian INGO within the field of migration - came to undertake the task of embedding and NGOizing global civil society agency within the GFMD process. It was a mission instrumentalized on the occasion of the Stockholm CSD/GFMD through founding the Migration and Development Civil Society Network (MADE), predominantly funded by European governments and largely loyal to preferences inscribed in the mainstream EU migration governance framework. The ICMC was also accorded a gate-keeping role in channelling GFMD-related funding earmarked for financing participation of civil society delegates in the CSD and thereby, indirectly, also in the PGA summits adjacent to the GFMD/CSD.

In the case of the Stockholm GFMD, 2014, the type of screening process criticized by the Global Unions in New York could be observed in action on the (Swedish) national level. Here, the ICMC's local Swedish sister organization, Caritas Sweden, was, on behalf of the ICMC and in close collaboration with the Swedish government, put in charge of the preparatory selection of delegates for the CSD and CS of that year's GFMD. From our discussions with the migration policy responsible in the Swedish Trade Union Confederation (LO) during the Spring of 2014, we could record frustration and anger, similar to what was expressed in the Global Unions' letter to the UN General Secretary in 2013. It was provoked by feelings of belittlement, without the space for expressing views, which diverged from those of the Swedish government and the dominant GFMD line. It appeared decisive for a remarkable absence of interest, from the unions, in the CSD and in a PGA, which had - void of independent funding sources - at this stage, become highly dependent on the ICMC which was now in command of screening and financing civil society delegates to the GFMD. Through this, the ICMC was also indirectly responsible for the participation of the very same individuals in the PGA, in advance of the GFMD. A similar critique from the unions, as in New York, 2013, and Stockholm 2014, was made in a briefing paper by Global Unions (2015) on the GFMD process in Istanbul 2015. The paper expressed concerns about the slow progress made by the GFMD in terms of 
accountability, transparency, and inclusivity, and about a growing impact of the business community in migration policy, with unions and civil society in general relegated to a peripheral space. It opted for an ILO-led tripartite model of consultations in partnership with migrant workers' associations.

On the background of a frail impetus and a flagging coherence of civil society, in particular concerning the partnership between unions and other civil society actors, the PGA meeting in Istanbul was to become a turning point, marked by self-critical reflection. At this meeting, preceding the Istanbul GFMD, the aforementioned William Gois expressed clearly what it meant in terms of nostalgia 'for the spirit that once existed' in pondering: ${ }^{5}$ 'We thought that we have a synchronised focus on Human Rights. We started losing that spirit and have to go back to the roots ... we have to find it again'. Comments from the floor further clarified what is at stake with the PGA: 'It is being institutionalised ... Rather than to speak about what is the real agenda we are spending too much time on who is chairing discussions in the CSD/CS ... While becoming a chair you cannot criticise'.

\section{Enigmas of civic activism: straddling policy, political, and democratic spaces}

This 'losing of the spirit' and becoming institutionalized within invited spaces related to neoliberal governance is, evidently not particular for the PGA, but generally problematic, widely discussed among civil society activists as well as in the social sciences.

Gaventa (2006, p. 23), for one, argues in discussing new spaces emerging around the world and aiming to promote opportunities for citizen engagement in policy processes, that creating new institutional arrangements will not lead to profound policy change. Rather he claims, this will depend on the nature of the power relations, in which new, potentially more democratic, spaces are embedded. He raises a number of critical questions related to issues of the democratic within invited spaces:

Does this new terrain represent a real shift in power? Does it really open up spaces where participation and citizen voice can have an influence? Will increased engagement within them risk simply re-legitimating the status quo, or will it contribute to transforming patterns of exclusion and social injustice and to challenging power relationships? (Gaventa, 2006, p. 23)

This kind of understanding can be applied to the position of the PGA and the CSD/CS within spaces for invited deliberation (the UN, GFMD, etc.). The rhetoric of participation and the use of the same language on human rights (within the PGA, the UN, and the GFMD), as William Gois referred to in the PGA meeting in New York (parallel to the UNHLD) 2013, corresponds to Gaventa's (2006, p. 23) reflections on the limits of new arrangements, which call for 'co-governance' and 'participatory governance'. Can they actually, he asks, 'challenge our traditional categories of the rulers and the ruled, the policymakers and the public'?

What is at stake could be captured by what Miraftab $(2004,2009)$ discusses in terms of 'symbolic inclusion'. It relates to multifaceted forms of power and dominance within a rhetoric of so-called partnership and shared ownership. As Gaventa explains, when used by large, powerful actors such as the World Bank and the International Monetary Fund to 'invite engagement on a "level playing field" [this] obscures inequalities of resources and power', it blurs 'traditional "us" and "them" distinctions between economic power holders and those who might negatively be affected by their corporate practices' (Gaventa, 2006, p. 23). The argument points at the distinction between power with (cooperation, collective action, alliance-building) and power over (domination), which neutralizes power to act, that is activism. But power with - that is building links between situated knowledge and mobilisation and broader international advocacy work' is essential for the making of a political 
space - a point of departure for collective action, 'in order to challenge global economic power' (Gaventa, 2006, pp. 25-26).

But, what is then political space? The political can start with being situated within new terrains of invited space for citizens' dialogues that correspond to the meaning of space as a dynamic social field of struggles; 'a social product', humanly constructed and including control, domination and power relations (Gaventa, 2006, p. 26). ${ }^{6}$ If we apply this perspective to the PGA as a global migrant network, it is important to emphasize the distinction between policy space and political space. While the former refers to meeting places for deliberation between citizens and policymakers (such as the GFMD's 'CS'), the latter relates to institutional channels, political discourses and practices through which precarious people and contending organizations working with them can pursue social justice, human rights and poverty reduction (cf. Gaventa, 2006, p. 26). Although these questions are inherent within regular documents formulated at PGA meetings, which address the UN and the GFMD, the primary expectations of PGA members are focused on realizing genuine democratic dialogue and influencing the global governance regime politically. It implicates, in consequence, what Gaventa refers to as democratic space; a space in which citizens can engage to claim citizenship and affect governance processes' (Gaventa, 2006, p. 26, with reference to Cornwall \& Coehlo, 2006). It would lend substance to the idea of 'invited dialogue' within, for example, the CS as a meeting place for deliberation between civil society, states, and international organizations within the GFMD framework. Such an 'invited space' ought, with reference to the expectations of PGA delegates, to be 'democratic spaces' related to, as formulated in general terms by Gaventa (2006, p. 26), 'opportunities, moments and channels where citizens can act to potentially affect policies, discourses, decisions and relationships that affect their lives and interests'.

However, as evident from deliberations at the PGA meeting in Istanbul 2015, the actually existing policy space in the GFMD process hardly functions as a democratic space from the perspective of civil society. The institutionalization of civil society is not necessarily counterproductive in itself, but can bring with it a tamed and de-politicized NGOization if controlled by the self-same dominant political and economic interests; the politics and policies, which have originally been the object of contestation. It is an enigma observed, in the global north as well as the south, as imminent in the staging of invited spaces. ${ }^{7}$ This, in turn, implicates the necessity of a continuous revival and renewal of civil society alliances in order to develop a counterhegemonic network of equivalence that amalgamates multiple subject positions within a powerful coalitional movement: that is, to constantly strengthen a composite movement from within. This is a still unsettled issue. It has been the object of critical/selfcritical debate in Istanbul 2015, and has continued in PGA venues in both Dhaka 2016 and in Berlin 2017, with a conceivably more potent and less disciplinary financial/organizational backing that those in for example Stockholm and Istanbul.

The discussions at the Berlin PGA meeting in 2017 contended that the PGA, and the wider institutionalized and permanent civil society fora which have originally emanated from it (e.g. GCM and MADE), need to reconnect to activist, radical and fundamental beliefs, and responsibilities (PGA, Panel 3 on 'Institutional Obstacles'). Envisaging its upcoming venue in Morocco in 2018, the PGA's still essential mission was stressed, regionally as well a globally. The need for a critical perspective on civil society actors captured by government interests was emphasized, as well as the need for strengthening autonomy through the revitalization of regional and global alliances. In this perspective, participants pointed to the importance of strengthening partnerships with labour unions. Others emphasized the strengthening of bonds with fora outside the narrow purview of the GFMD, such as the WSFM; an invented space, which sprung from the WSF, with similar visions 
as those originally grounding the PGA, but wider autonomy. After all, in spite of a discouraging experience, at times, for many activists, the original radically critical values and positions of the PGA as an invented space remain a fundamental platform.

\section{Contestation or appropriation? Vagaries of an inside-outside strategy}

As we have laid out in the preceding discussion, there are obvious problems connected with contemporary movement strategies bound into an ambiguous position as both participating in 'dialogue' within 'invited spaces' and with counterhegemonic ambitions to transform existing power relations. We have illustrated this with the case of the PGA as a global movement in the making, positioning itself as counterpoised to the intergovernmental forum of the GFMD. Recording self-reflections of movement activists in the PGA in the course of the 2013 UNHLD, and later in Stockholm 2014, Istanbul 2015, and Berlin 2017, we have depicted this mission as connected to risks of a depoliticizing co-optation. Without subscribing outright to the idea of a universal 'stage model' (Coy \& Hedeen, 2007 [2005]), we do see, in conclusion, co-optation as a complex amalgamating process, beyond single acts or particular events, as expressed on different levels and as potentially incremental, typically proceeding through consecutive and tendentially cumulative steps.

The start of the PGA as nodal point for a contending movement was, seen in this perspective, marked by the inception of a collective global engagement. It was focused on what had been identified as a widely shared issue of dispossession and social justice with activists representing the global south at the forefront. It was premised on the identification of a multitude of civil society actors with joint demands for change to be advanced through an 'inside-outside' contestative strategy, sustained by a globally extended 'network of equivalence'. It called, from the perspective of migrant organizations and migrant advocacy NGOs/INGO's, for the rapport with powerful, but every so often ambivalent, allies among global unions. This was based on struggles over the precarity of contemporary labour relations; nationally, regionally, and globally. We have illustrated vagaries connected with managing this puzzle through the course of events at the UNHLD in New York 2013. Therefore, we could witness, on site, an already ambivalent positionality of the labour unions, becoming exacerbated by their progressive marginalization in the context of a covert process of inclusionary, but selective and subordinating, hegemony management by governments, business interests, powerful international organizations, and the chosen gate-keeping humanitarian INGOs.

A powerful marker of co-optation was, at this stage, the parallel, almost universal appropriation by governments of the discourse of 'human rights', hitherto flown as the frontal parole of civil society; yet henceforth (as captured by disorientated self-reflection of movements activists) as a floating, and tendentially 'empty', non-obliging signifier. In essence, a moral 'last utopia' (Moyn, 2010) in the age of neoliberal globalization where the twentieth century's totalizing ideopolitical conceptions of 'social justice' have been declared dead by default. Yet, as contended by Moyn (2010, p. 227), if human rights shall relate to 'core values that demand protection they cannot be all things to all people ... the last utopia cannot be a moral one'. A moral discourse of 'human rights', but without a distinct prominence of labour rights and labour protection, and social rights in general, is of limited interest to trade unions in particular. The Stockholm GFMD was marked by a further step towards co-optation of civil society via a transition from the appropriation of movement language to a condition of in-depth 'institutional appropriation' (Coy \& Hedeen, 2007 [2005]). It was a process also signified by the tendential assimilation of movement leaders and movement programmes, bound up through financial control by a powerful humanitarian INGO as the gatekeeper (the ICMC). We have, in tandem with a global policy shift, depicted this process of increasingly deep-seated appropriation 
of a movement in the making - thereby tendentially 'unmaking it' - as intertwined with a process of consensual hegemony making. It is, more specifically, spun around an appropriative and dispossessing so-called win-win-win formula of 'managed migration', prioritizing the local and global interests of employers and migrant receiving countries.

Let us, in this vein, conclude by quoting Brubaker's ${ }^{8}$ comment that 'in relationships marked by power imbalances, cooperation and co-optation are nearly indistinguishable'. The implications appear clear, and the concept of 'space' is of discriminating importance. While the PGA and similar civic networks and movements of civil society are struggling to gain influence within formal 'invited spaces', they need to continuously critically recreate and consolidate their own 'invented spaces', in order to be able to develop a sustainable capacity as counterhegemonic political subjects. This implicates, among others, as addressed by movement activists in Berlin, a revived process of transversal dialogue bringing the unions solidly back into a strengthened, more autonomous and sustainable 'network of equivalence'.

\section{Notes}

1. Information on the history and politics of the PGA is available at, among others: http:// peoplesglobalaction.org/about/history/.

2. Represented by, e.g. the International Assembly of Migrants and Refugees (Rother, 2013).

3. Founded in connection with the PGA meeting connected with the GFMD in Geneva, 2011.

4. See Triandafyllidou (2013) and Fudge and Strauss (2013) for critical analyses of schemes of circular and temporary migration (2013).

5. Referring, in particular, to the PGA summit in Manila, 2008.

6. Referring to Lefebvre (1991) and Cornwall (2002).

7. For example, Wikström and Lundström (2002), Kaldor (2003), Veltmeyer (2009), Neocosmos (2011), Léon-Rosales and Ålund (2017).

8. Brubaker (2003), quoted in Coy and Hedeen (2007 [2005]).

\section{Disclosure statement}

No potential conflict of interest was reported by the authors.

\section{Funding}

This article is a contribution to the Swedish Research Links project, 'Migration and development. What space for civil society in global governance? (MIGLINK)', with financial support through the Swedish Research Council [grant number 348-2013-6682].

\section{Notes on Contributors}

Aleksandra Alund is a Professor at REMESO, The Institute for Research on Migration, Ethnicity and Society at Linköping University. She has published widely on in Swedish, English, and other languages on international migration and ethnicity, identity, culture, gender, youth, and social movements. Her latest publications address issues of democracy and urban justice movements and include Reimaginieering the nation, essays on twentyfirst-century Sweden (co-edited with Carl-Ulrik Schierup and Anders Neergaard, Peter Lang, 2017)

Carl-Ulrik Schierup is a Professor at the Institute for Research on Migration, Ethnicity and Society (REMESO), Linköping University. He has a disciplinary background in Social Anthropology and Sociology. He has published on issues of international migration and ethnic relations, globalization, nationalism, multiculturalism, citizenship, working-life, and labour relations. He has co-edited Migration, precarity and global governance: Challenges and opportunities for labour (Oxford University Press, 2015). 


\section{References}

Ålund, A., Schierup, C.-U., \& Neergaard, A. (2017). Reimagineering the nation. Essays on twenty first century Sweden. Frankfurt am Main: Peter Lang.

Brock, K., Gaventa, J., \& Cornwall, A. (2001). Power, knowledge and political spaces in the framing of poverty policy. Brighton: IDS.

Brown, W. (2005). Edgework: Critical essays on knowledge and politics. Princeton, NJ: Princeton University Press.

Brubaker, D. (2003, April 3-7). Personal comments during discussion at 'Restorative Justice and Conflict Transformation: Friends or Foes' presentation by Michelle Armster and Lorraine Stutzman-Amstutz at NCPCR-PeaceWeb Conference, April 6, 2003, Atlanta, Georgia.

Cornwall, A. (2002). Locating citizen participation. IDS Bulletin, 33(2), 49-58.

Cornwall, A., \& Coehlo, V. (Ed.). (2006). Spaces for change? The politics of citizen participation in new democratic arenas. London: Zed Books.

Cox, R. W. (1983). Gramsci, hegemony, and international relations: An essay in method. Millennium: Journal of International Studies, 12(1), 162-175.

Coy, P. G., \& Hedeen, T. (2007 [2005]). A stage model of social movement cooptation: Community mediation in the United States. Retrieved from https://eds-a-ebscohost-com.e.bibl.liu.se/eds/detail/detail?vid=2\&sid= 259e066a-bcdd-49a5-9712-be8bdde4819f@sessionmgr4006\&bdata=JnNpdGU9ZWRzLWxpdmUmc2Nvc GU9c210ZQ==\#AN=17567536\&db=edb

Deak, A. (2005). The condition of hegemony and the possibility of resistance. Undercurrent, 2(3), 46-56.

Feixa, C., Pereira, I., \& Juris, J. (2009). Global citizenship and the 'new, new' social movements. Iberian connections. Young, 17(4), 421-442.

Flecker, K. (2011). Model program - or mistake? Canada's temporary foreign worker program (TFWP). Toronto: Canadian Labour Congress.

Flecker, K. (2014). Not wanted on the voyage. Migrant workers' needs and rights continue to be ignored. The Monitor. Retrieved from https://www.policyalternatives.ca/publications/monitor/not-wanted-voyage

Fudge, J., \& Strauss, K. (Eds.) (2013). Temporary work, agencies, and unfree labor. Insecurity in the new world of work. New York, NY: Routledge.

Funke, P. N. (2014). Building rhizomatic social movements? Movement-building relays during the current epoch of contention. Studies in Social Justice, 8(1), 27-44.

Gaventa, J. (2006). Finding the spaces for change: A power analysis. IDS Bulletin, 37(6), 23-33.

Gill, S. (2003). Power and resistance in the new world order. London: Palgrave.

Global Unions. (2013). Open letter to United Nations Secretary General Ban Ki-moon concerning trade union and civil society inclusion at the High-level Dialogue on Migration and Development New York, October 34, 2013. Public Services International. Retrieved from http://world-psi.org/en/support-our-action-sign-letter

Global Unions. (2015). Global unions briefing paper: 2015 Global Forum on Migration and Development. Brussels: Author.

Gramsci, A. (1971). Selections from the prison notebooks of Antonio Gramsci. (H. Quinton \& G. N. Smith, Eds.), New York, NY: International.

Hall, S. (1987, June). Gramsci and us. Marxism Today, pp. 16-21.

Kaldor, M. (2003). Global civil society. An answer to War. Cambridge: Polity Press.

Laclau, E., \& Mouffe, C. (1985). Hegemony and socialist strategy. London: Verso.

Lefebvre, H. (1991). The production of space. London: Verso.

Léon-Rosales, R., \& Ålund, A. (2017). Renaissance from the margins - Urban youth activism in Sweden". In A. Ålund, C.-U. Schierup, \& A. Neergaard (Eds.), Reimaginiering the nation. Essays on Swedish society (pp. 351-374). Frankfurt am Main: Peter Lang.

Likic-Brboric, B., Schierup, C.-U. (2015). Labour rights as human rights? Trajectories in the global governance of migration. In C.-U. Schierup (Ed.), Migration, precarity and global governance (pp. 223-244). Challenges for labour. Oxford: Oxford University Press.

Lister, R. (1996, July 16-18). Citizenship: Towards a feminist synthesis. The Conference: Women and Citizenship, University of Greenwich, London.

Melucci, A. (1989). Nomads of the present social movements and individual needs in contemporary society. Philadelphia, PA: Temple University Press. 
Miraftab, F. (2004). Invited and invented spaces of participation: Neoliberal citizenship and feminists' expanded notion of politics. Wagadu, 1(Spring 2004), 1-7.

Miraftab, F. (2009). Insurgent planning: Situating radical planning in the global south. Planning Theory, 32(8), 32-50.

Motta, S. C. (2011). Notes towards prefigurative epistemologies. In S. C. Motta, \& A. G. Nilsen (Eds.), Social movements in the global south. Dispossession, development and resistence (pp. 178-199). Houndmills: Palgrave Macmillan.

Moyn, S. (2010). The last utopia: Human rights in history. London: Belknap.

Neocosmos, M. (2011). Transition, human rights and violence: Rethinking a liberal political relationship in the African neo-colony. Interface: A Journal for and About Social Movements, 3(2), 359-399.

Offe, C. (1985). New social movements: Challenging the boundaries of institutional politics. Social Research, 52 (4), 817-868.

People's Global Action. (2010). 2010 Peoples Global Action on migration development. MFA, Migrant Forum in Asia. Retrieved from http://mfasia.org/2010-peoples-global-action-on-migration-development/

Piper, N. (2015). Democratising migration from the bottom up: The rise of the global migrant rights movement. Globalizations, 12(5), 788-802.

Piper, N., Grugel, J. (2015). Global migration governance, social movements and the difficulties of promoting migrant rights. In C.-U. Schierup (Ed.), Migration, precarity and global governance. Challenges for labour (preliminary title) (pp. 261-279). Oxford: Oxford University Press.

Polanyi, K. (2001 [1944]). The great transformation: The political and economic origins of our time. Boston, MA: Beacon Press.

Purcell, M. (2009a). Hegemony and difference in political movements: Articulating networks of equivalence. New Political Science, 31(3), 291-317.

Purcell, M. (2009b). Resisting neoliberalization: Communicative planning or counter-hegemonic movements? Planning Theory, 8(2), 140-165.

Rother, S. (2009). 'Inside-Outside' or 'outsiders by choice'? Civil society strategies towards the 2nd Global Forum on Migration and Development (GFMD) in Manila. Asien, 111(April), 95-107.

Rother, S. (2013). A tale of two tactics: Civil society and competing visions of global migration governance from below. In M. Geiger \& A. Pécoud (Eds.), Disciplining the transnational mobility of people (pp. 41-62). Houndmills: Macmillan.

Schierup, C.-U., Ålund, A., \& Likić-Brborić, B. (2015). Migration, precarization and the democratic deficit in global governance. International Migration, 53(3), 50-63.

Schierup, C.-U., Munck, R., Likic-Brboric, B., Neergaard, A. (2015). Introduction: Migration, precarity and global governance: Challenges and opportunities for labour. In C.-U. Schierup (Ed.), Migration, precarity and global governance. Challenges and opportunities for labour (pp. 1-24). Oxford: Oxford University Press.

Touraine, A. (1987). Social movements: Participation and protest. Scandinavian Political Studies, 10(3), 207-222.

Triandafyllidou, A. (Ed.). (2013). Circular migration between Europe and its neighbourhood. Choice or necessity? Oxford: Oxford University Press.

Veltmeyer, H. (2009). Democratic governance and participatory development: The role of development NGOs. The Whitehead Journal of Diplomacy and International Relations, 6(Summer/Fall), 89-109.

Walton, J., \& Udayagiri, M. (2003). Global transformation and local counter movements: The prospects for democracy under neoliberalism. International Journal of Comparative Sociology, 44, 309-343.

Wikström, F., \& Lundström, T. (2002). Den ideella sektorn: Organisationerna i det civila samhället. Stockholm: Sober Förlag/European Civil Society Press.

Yuval-Davis, N. (1999). What is 'transversal politics'. Soundings, 12, 94-98. 